\title{
A positive role for PEA3 in HER2-mediated breast tumour progression
}

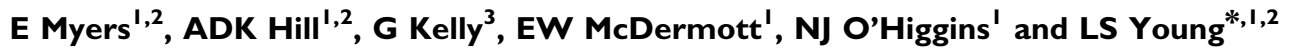 \\ 'School of Medicine and Medical Science, Saint Vincent's University Hospital, Dublin, Ireland; ${ }^{2}$ Conway Institute, University College Dublin, Dublin, Ireland; \\ ${ }^{3}$ School of Mathematical Sciences, Dublin, Ireland
}

Overexpression of HER2 is associated with an adverse prognosis in breast cancer. Despite this, the mechanism of its transcriptional regulation remains poorly understood. PEA3, a MAP kinase (MAPK)-activated member of the Ets transcription factor family has been implicated in the transcriptional regulation of HER2. The direction of its modulation remains controversial. We assessed relative levels of PEA3 expression and DNA binding in primary breast cultures derived from patient tumours $(n=18)$ in the presence of an activated MAPK pathway using Western blotting and shift analysis. Expression of PEA3 in breast tumours from patients of known HER2 status $(n=107)$ was examined by immunohistochemistry. In primary breast cancer cell cultures, growth factors induced interaction between PEA3 and its DNA response element. Upregulation of PEA3 expression in the presence of growth factors associated with HER2 positivity and axillary lymph node metastasis $(P=0.034$ and 0.049 , respectively). PEA3 expression in breast cancer tissue associated with reduced disease-free survival $(P<0.00 \mathrm{I})$, Grade III tumours $(P<0.000 \mathrm{I})$ and axillary lymph node metastasis $(P=0.026)$. Co-expression of PEA3 and HER2 significantly associated with rate of recurrence compared to patients who expressed HER2 alone $(P=0.0039)$. These data support a positive role for PEA3 in HER2-mediated oncogenesis in breast cancer. British Journal of Cancer (2006) 95, 1404- |409. doi:I0.1038/sj.bjc.6603427 www.bjcancer.com

Published online 24 October 2006

(c) 2006 Cancer Research UK

Keywords: PEA3; HER2; breast cancer; Ets transcription factor

HER2 encodes for a $185 \mathrm{kDa}$ transmembrane glycoprotein receptor which is structurally related to the epidermal growth factor receptor family. Overexpression of HER 2 occurs in $20-30 \%$ of breast cancer, and is associated with poorly differentiated and highly proliferative tumours (Sorlie et al, 2001). These tumours tend to be resistant to endocrine therapies and are associated with a decrease in overall survival (Berns et al, 1995; Carlomagno et al, 1996). The monoclonal antibody, trastuzumab (herceptin), targets the HER2 receptor and is an effective therapy in recurrent breast cancers that overexpress HER2 (Vogel et al, 2002). Despite the prognostic significance of HER2 and the existence of a therapeutic agent, many questions about HER2's role and that of trastuzumab remain. Unfortunately, just as oestrogen receptor (ER) status imperfectly predicts response to endocrine therapy, HER2 expression imperfectly predicts response to trastuzumab (Menard et al, 2003). In addition, despite the increased aggressiveness associated with HER2 overexpression, the precise mechanism of HER2 regulation is incompletely understood. Previous studies have implicated growth factor-related transcription factors in HER2 overexpressing breast cancers (Goel and Janknecht, 2003). Ets proteins are a family of mitogen-activated protein kinase (MAPK)-dependant transcription factors. They have been shown to be present in primary human breast cancers and their expression has been associated with disease progression and metastasis (Shepherd et al, 2001; Span et al, 2002). Ets transcription

*Correspondence: Dr LS Young, Surgical Research Group, Royal College of Surgeons in Ireland, York House, York Street, Dublin 2, Ireland; E-mail: lyoung@rcsi.ie

Received 27 April 2006; revised 15 August 2006; accepted I5 September 2006; published online 24 October 2006 factors regulate target gene expression by binding to Ets response elements in the promoter region of the relevant target gene. The HER2 upstream regulatory region contains a conserved Ets-binding site and mutation of this sequence reduces transcription of linked reporter genes in several different mammalian cell lines, including breast tumour cell lines (Scott et al, 1994). These findings are consistent with the hypothesis that one of the Ets proteins may regulate transcription of the HER2 gene and may account for its increased expression in breast tumour cells. PEA3 (E1AF) is an Ets family member, and previous molecular studies have implicated PEA3 in the regulation of HER2 transcription. Shepherd et al (2001) has suggested that PEA3 has the potential to positively regulate HER2 transcription. Conversely, another study suggests that PEA3 represses HER2 promoter-reporter expression in a human ovarian and a human breast carcinoma cell line (Xing et al, 2000), and Xia et al (2006) have suggested that PEA3 expression does not correlate with HER2 expression in human breast cancer. These conflicting studies prompted us to undertake ex vivo studies in human breast tissue and in primary cell cultures derived from patient tumours. We hypothesise that PEA3 expression may be associated either directly or indirectly with HER2 status and that it may be influenced by an activated MAPK pathway. We propose that the direction of these relationships would support either a positive or a negative role for PEA3 in HER2-mediated breast tumorigenesis.

\section{MATERIALS AND METHODS}

\section{Patient selection}

Following ethical approval, 107 breast tumour specimens and six reduction mammoplasties were included in this study. All patients 
were free of distant metastasis at presentation and were assessed by abdominal ultrasound, chest X-ray and bone scintigraphy before surgery. All patients received chemotherapy and tamoxifen $\left(20 \mathrm{mg} \mathrm{day}^{-1}\right)$ for a maximum of 5 years. In those patients who were ER-negative, tamoxifen was prescribed on the basis of the fact that the patients were PR-positive.

\section{Cell culture stimulations}

Following ethical approval, breast tumour specimens were obtained from 18 patients undergoing surgery for removal of a histologically confirmed breast tumour. Breast tumour cell cultures were established and validated as described previously (Myers et al, 2004, 2005). In brief, primary tumour epithelial cells were extracted in HBSS without calcium or magnesium (Gibco, Paisley, Scotland) supplemented with $1 \mu \mathrm{M}$ EDTA and $1 \mu \mathrm{M}$ DTT for $40 \mathrm{~min}$. Cells were cultured in RPMI containing $5 \mu \mathrm{g} \mathrm{ml}^{-1}$ insulin, $10 \mu \mathrm{g} \mathrm{ml}^{-1}$ transferrin, $30 \mathrm{nM}$ sodium selinate, $10 \mathrm{nM}$ hydrocortisone, $10 \mathrm{~nm} \beta$-estradiol, $10 \mathrm{~mm}$ HEPES, $2 \mathrm{~mm}$ glutamine, $10 \%$ foetal calf serum $\left(\mathrm{wv}^{-1}\right)$ and $5 \%$ ultroser $\mathrm{G}$ on a growth factor-reduced matirgel matrix (BD Biosciences, San Jose, CA, USA) $\left(60 \mathrm{ng} \mathrm{cm}^{-2}\right)$. Examination of primary breast cultures by staining with ethidium bromide and flow cytometric analysis using the phycoerythrin (PE)-labelled pan-leukocyte marker (CD45 RA and RO), confirmed cell viability and epithelial origin of tumour cells (Myers et al, 2004). Phenotypically distinct progenitor epithelial cell populations within the mammary epithelium were characterised by flow cytometry using a PE-conjugated mouse anti-human EpCAM (epithelial-specific antigen) antibody and FITC-conjugated mouse anti-human CD227 (MUC1) monoclonal mouse antibody (BD Biosciences). Bipotent progenitors $\left(\mathrm{EpCAM}^{+} \mathrm{MUC1}^{-}\right)$which can generate both luminal and myoepithelial cells were found to represent $51.9 \%$ of the epithelial cell population, whereas the luminal-restricted progenitor $\left(\mathrm{EpCAM}^{+} \mathrm{MUC}^{+}\right)$were found to represent $48.1 \%$. Cells were incubated in a humidified atmosphere of $5 \% \mathrm{CO}_{2}$ at $37^{\circ} \mathrm{C}$. Experiments were carried out when cells reached $90 \%$ confluence. Cells were serum and steroid depleted for $24 \mathrm{~h}$ before treatment and then incubated in the presence and absence of bFGF or EGF for $24 \mathrm{~h}$ and harvested. Total protein was extracted using lysis buffer (1\% Ipegal, $0.5 \%$ deoxycholic acid, $0.1 \%$ SDS and $1 \times$ PBS) with pefabloc $\left(5 \mu \mathrm{g} \mathrm{ml}^{-1}\right)$. Cell lysates were subsequently normalised for protein content.

\section{Western blotting}

Proteins $(100 \mu \mathrm{g})$ were resolved on a $12 \%$ polyacrylamide gel at $110 \mathrm{~V}$ for $120 \mathrm{~min}$ and were transferred to a nitrocellulose membrane $(250 \mathrm{~mA}$ for $60 \mathrm{~min})$. Membranes were incubated for $60 \mathrm{~min}$ in blocking buffer ( $5 \%$ non-fat dry milk, $0.1 \%$ Tween in PBS) at room temperature and subsequently with primary antibody, mouse anti-human PEA3 $\left(10 \mu \mathrm{g} \mathrm{ml}^{-1}\right.$ ) (Santa Cruz Biotechnology Inc., Sc-113) in blocking buffer overnight at $4^{\circ} \mathrm{C}$. The membranes were washed before incubation with the corresponding horseradish peroxidase secondary antibody (Santa Cruz Biotechnology Inc.) (one in 2000) in blocking buffer for $60 \mathrm{~min}$ at room temperature. The membranes were washed and developed with intensified luminescence (Pierce, IL, USA). K-562 cells (Santa Cruz Biotechnology Inc.) were used as a positive control for PEA3.

\section{Electrophoretic mobility shift assays}

Nuclear protein was extracted using a Ner/Per kit according to the manufacturer's instructions (Pierce). For electrophoretic mobility shift assay, $1 \mu \mathrm{g}$ of nuclear extract was incubated for $30 \mathrm{~min}$ in the presence of $20 \mathrm{~mm}$ HEPES ( $\mathrm{pH} 7.9$ ), $5 \mathrm{~mm} \mathrm{MgCl}_{2}, 20 \%$ glycerol,

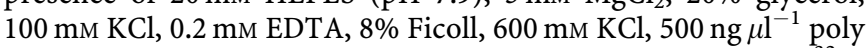
$\mathrm{dI} \mathrm{dC}$ (deoxyinosinic-dexycytidylic) acid, $50 \mathrm{~mm}$ DTT and $\alpha^{32} \mathrm{P}$ -
dCTP-labelled double-stranded oligonucleotide for Ets, response element. Oligonucleotides were designed to incorporate the native human HER2/ERBB2 (NM_001005852) promoter $(-287$ to -270$)$ $5^{\prime}$-CATGGCCTAGGGAATTTATCC-3', with the consensus sequence of Ets-binding elements underlined. For supershift experiments, antibodies against PEA3 were added following the initial incubation, and samples were then incubated for a further $20 \mathrm{~min}$. The samples were electrophoresed through a $5.5 \%$ nondenaturing polyacrylamide gel in $0.5 \times$ Tris-borate-EDTA buffer. For competition studies, the reaction was performed as described with $50 \times$ molar excess of unlabelled probe. Supershift negative controls were performed using matched IgG control.

\section{Immunohistochemistry and immunofluorescence}

Five micron thick tissue sections were cut from paraffin-embedded breast tumour tissue blocks and mounted on Superfrost Plus slides (BDH, Poole, UK). Sections were dewaxed, rehydrated and washed in PBS. PEA3 was detected as described previously (Fleming et al, 2004). Briefly, sections were blocked in serum for $90 \mathrm{~min}$. Sections were incubated with the primary antibody, mouse anti-human PEA3 $\left(10 \mu \mathrm{g} \mathrm{ml}^{-1}\right)$ and rabbit anti-human Phospho-raf $(1: 50)$ (Cell signalling, Beverly, MA, USA) for $60 \mathrm{~min}$ at room temperature. Subsequently, sections were incubated in the corresponding biotin-labelled secondary antibody (one in 2000) for $30 \mathrm{~min}$, followed by peroxidase-labelled avidin-biotin complex. Sections were developed in 3,3-diaminobenzidine (DAB) tetrahydrochloride and counterstained with haematoxylin. Negative controls were performed using matched IgG controls (DAKO, Glostrup, Denmark). Immunostained slides were scored for PEA3 and Phospho-raf using the Allred scoring system (Harvey et al, 1999). HER2 status was evaluated using the DAKO (Glostrup, Denmark) HercepTest immunocytochemical assay. Scoring was assessed according to the manufacturer's instructions. A score was assigned according to the intensity and pattern of cell membrane staining: 0 to $+1=$ no staining, or staining in $<10 \%$ of cells; $+2=$ weak to moderate staining in $>10 \%$ of cells; $+3=$ strong staining in $>10 \%$ of cells. Sections were examined under a light microscope. Independent observers, without knowledge of prognostic factors, scored slides. Immunofluorescence detection of PEA3 was performed on primary breast cancer tissue. Cells and tissues were prepared as described above. Breast cancer cells and sections were blocked in $1.5 \%$ normal serum and then incubated with $20 \mu \mathrm{g} \mathrm{ml}^{-1}$ mouse anti-human PEA3 in 10\% human serum for $90 \mathrm{~min}$. Cells and sections were subsequently incubated with Alexa Fluor 546conjugated secondary antibody (Molecular Probes, Invitrogen, Paisley, UK) for $60 \mathrm{~min}$ and were counterstained with DAPI (Sigma-Aldrich, Dorset, UK). Confocal microscopy was performed using a confocal microscope (Zeiss LSM 510 UV META system, Standart Gottingen, Germany) and images were captured using Laser Capture software, Zeiss, Standart Gottingen, Germany.

\section{Clinicopathological parameters}

Variables analysed included tumour grade, axillary nodal status and ER status. A recurrence was defined as any local (chest wall) or systemic recurrence during the follow-up period.

\section{Statistical analysis}

Statistical analysis was carried out using the Fisher's exact test for categorical variables to compare two proportions. Kaplan-Meier estimates of survival functions were computed and the Wilcoxon test was used to compare survival curves. In addition, the Wilcoxon rank sum test was used to compare two medians. Two-sided $P$-values of $<0.05$ were considered to be statistically significant. 


\section{RESULTS}

\section{Growth factor induction of PEA3 and recruitment to the HER2 promoter in breast cancer cells}

The ability of growth factors bFGF and EGF to induce PEA3 expression in primary breast cancer cells derived from patient tumours was investigated by Western blotting. The transcription factor was expressed in a proportion of tumours (14 out of 18 tumours). Of tumours found positive for PEA3, increased expression was found in a subset of tumours in response to growth factor treatment (Figure 1A).

To determine the ability of PEA3 to bind to the Ets response element in the presence of growth factors, bFGF and EGF, gel shift assays were performed. Using oligonucleotide sequences, which are specific for the HER2 promoter, the ability of nuclear extracts from non-treated, primary breast cancer cell cultures to bind to the DNA response element was compared to cells treated with bFGF and EGF (Figure 1B). PEA3 response element binding was induced in the presence of both bFGF and in particular EGF in comparison to control. An immuno-depletion induced by pre-incubation of the nuclear extracts with anti- PEA3 established that PEA3 was present at the protein-DNA complex.

\section{Localisation of PEA3 and Phospho-raf in human breast cancer}

The transcription factor PEA3 was localised within paraffinembedded human breast tissue using immunohistochemistry. PEA3 was detected predominantly within the nuclei of invasive tumour epithelial cells, and to a lesser extent within the cytosol (Figure 2A). PEA3 protein was not detected in the normal surrounding breast tissue nor in the reduction mammoplasties, which were used as controls. This predominant nuclear localisation was confirmed by immunofluorescence (Figure 2C). PEA3 was
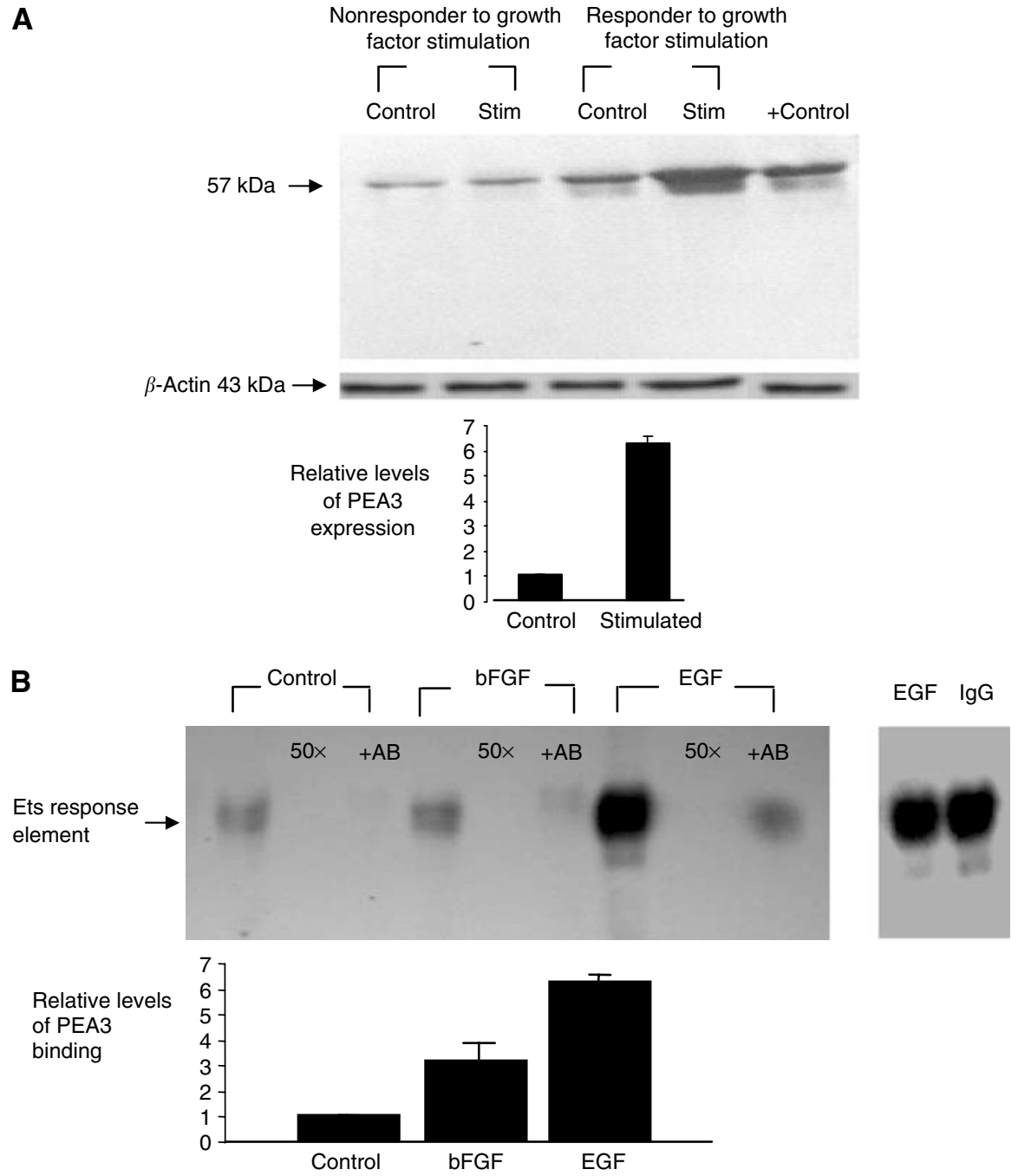

Figure I (A) Western blot analysis of PEA3 protein levels in primary breast cultures. Illustrative blots of primary tumour response to stimulation with either bFGF $\left(5 \mathrm{n} \mathrm{ml}^{-1}\right)$ or EGF $\left.(10 \mathrm{ng} \mathrm{m})^{-1}\right)$. Positive controls, K-562 $(+)$. Relative optical density of PEA3 immunoblots were obtained (Eagle Eye, Stratagene, CA, USA), optical density readings of control values were normalised to I and treated groups were expressed as a ratio. Results are expressed as mean \pm s.e.m. $(n=\mid 8)$. (B) Electrophoretic mobility shift analysis of nuclear extracts primary breast cancer cultures. Nuclear protein extracts from primary breast cancer cells in the presence and absence of bFGF and EGF were compared for increased binding to an $\alpha^{32}$ P-dCTP labelled Ets response element. DNA protein interactions were assayed in the presence of $50 \times$ molar excess of homologous oligonucleotide. Nuclear protein extracts were pre-incubated in the presence of anti-PEA3. Negative controls were performed using matched IgG. Relative optical densities of PEA3 immunoblots were performed. Optical density readings of control values were normalised to I and treated groups were expressed as a ratio. Results are expressed as mean \pm s.e.m. $(n=3)$. 
found to be expressed in $47 \%$ of breast tumour patients. As reported previously, expression of Phospho-raf was found within the nuclei of tumour epithelial cells with scant cytoplasmic staining (Myers et al, 2005) (Figure 2B).

\section{Associations between the expression of PEA3 and clinical variables/growth factor markers}

Associations between the qualitative expression of PEA3 and clinicopathological parameters were examined. Expression of the transcription factor, PEA3, was found to associate with both tumour grade and axillary lymph node positivity $(P<0.0001$ and 0.026 , respectively). A significant association was found between disease recurrence and expression of PEA3 $(P<0.0001)$. No relationship was detected between the transcription factor and ER status (Table 1). From Kaplan-Meier estimates of survival, PEA3 protein was found to significantly associate with time to disease recurrence $(P<0.001, n=107)$ (Figure $3 \mathrm{~A})$.

In line with previous observations (Fleming et al, 2004), a significant association was detected between PEA3 expression and that of HER2 $(P=0.0369)$ (Table 1$)$. The ability of breast cancer cells derived from patient tumours to regulate PEA3 protein expression in the presence of growth factors was related to clinicopathological parameters. Upregulation of PEA3 was detected in $66 \%$ ( 12 out of 18 tumours) of tumours. Relative increases in PEA3 protein expression are given in Table 2. Growth factor induction of PEA3 expression was found to significantly associate with axillary lymph node positivity and expression of HER2 ( $P=0.049$ and $P=0.034$, respectively). Co-expression of HER2 and PEA3 significantly associated with increased rate of recurrence, compared to patients who expressed HER2, but not PEA3 $(P=0.0039, n=32)$ (Figure 3B). In order to determine the association between PEA3 status and an activated MAPK pathway, expression of the MAPK protein Phospho-raf was examined. Phospho-raf expression significantly associated with PEA3 expression $(P<0.0001)($ Table 1$)$.

\section{DISCUSSION}

The HER2 (erbB2) gene encodes a $185-\mathrm{kDa}$ transmembrane receptor with tyrosine kinase activity and acts through intracellular

Table I Comparison of PEA3 expression with clinicopathological parameters and growth factor markers

\begin{tabular}{|c|c|c|c|c|}
\hline & Total & $\begin{array}{c}\text { PEA3-positive } \\
\text { (\%) }\end{array}$ & $\begin{array}{c}\text { PEA3-negative } \\
\text { (\%) }\end{array}$ & $P$-value \\
\hline $\begin{array}{l}\text { No. of patients } \\
\text { Mean age } \\
\text { Tumour size }(\mathrm{mm})\end{array}$ & 107 & $\begin{array}{c}50(47 \%) \\
47.94 \\
3.17\end{array}$ & $\begin{array}{c}57(53 \%) \\
51.90 \\
2.72\end{array}$ & $\begin{array}{l}- \\
0.0776 \\
0.0198\end{array}$ \\
\hline $\begin{array}{l}\text { Grade } \\
\quad \text { Grade } 3 \\
\text { Non-grade } 3\end{array}$ & $\begin{array}{l}55 \\
52\end{array}$ & $\begin{array}{l}37(67 \%) \\
13(25 \%)\end{array}$ & $\begin{array}{l}18(33 \%) \\
39(75 \%)\end{array}$ & $<0.0001$ \\
\hline $\begin{array}{c}\text { Axillary lymph node } \\
\text { Node-positive } \\
\text { Node-negative }\end{array}$ & $\begin{array}{l}\text { tatus } \\
69 \\
38\end{array}$ & $\begin{array}{l}38(55 \%) \\
12(32 \%)\end{array}$ & $\begin{array}{l}31(45 \%) \\
26(68 \%)\end{array}$ & 0.0260 \\
\hline $\begin{array}{l}\text { ER status } \\
\text { Positive } \\
\text { Negative }\end{array}$ & $\begin{array}{l}84 \\
23\end{array}$ & $\begin{array}{l}40(48 \%) \\
10(43 \%)\end{array}$ & $\begin{array}{l}44(52 \%) \\
13(57 \%\end{array}$ & 0.8154 \\
\hline $\begin{array}{l}\text { HER2 status } \\
\text { Positive } \\
\text { Negative }\end{array}$ & $\begin{array}{l}32 \\
75\end{array}$ & $\begin{array}{l}20(63 \%) \\
30(40 \%)\end{array}$ & $\begin{array}{l}12(37 \%) \\
45(60 \%)\end{array}$ & 0.0369 \\
\hline $\begin{array}{c}\text { Recurrence } \\
\text { Positive } \\
\text { Negative }\end{array}$ & $\begin{array}{l}23 \\
84\end{array}$ & $\begin{array}{l}20(87 \%) \\
30(36 \%)\end{array}$ & $\begin{array}{r}3(13 \%) \\
54(64 \%)\end{array}$ & $<0.000 \mid$ \\
\hline $\begin{array}{c}\text { Phospho-raf } \\
\text { Positive } \\
\text { Negative }\end{array}$ & $\begin{array}{l}37 \\
70\end{array}$ & $\begin{array}{l}31(84 \%) \\
19(27 \%)\end{array}$ & $\begin{array}{r}6(16 \%) \\
51(73 \%)\end{array}$ & $<0.0001$ \\
\hline
\end{tabular}

$E R=$ oestrogen receptor. Continuous variables were analysed using the two-sample t-test. Nominal variables were analysed using Fisher's exact test.
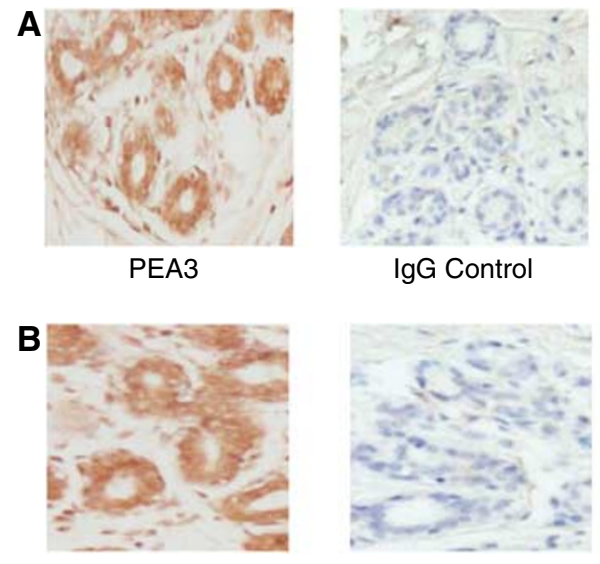

C Raf

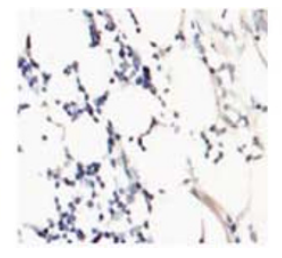

Normal

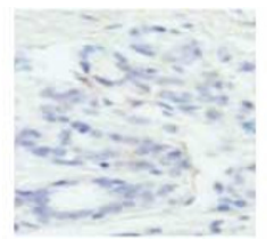

IgG Control

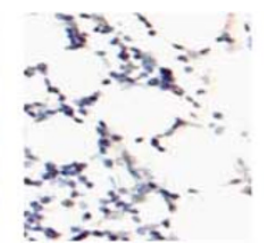

Normal
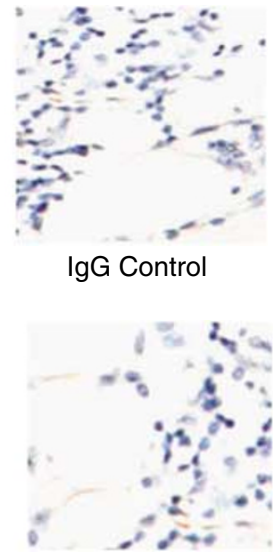

Control

C

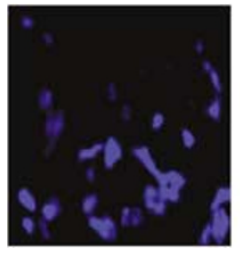

$D A P I$

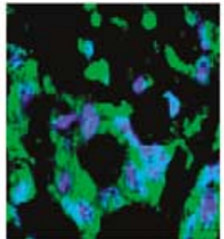

Anti-PBA3+DAPI

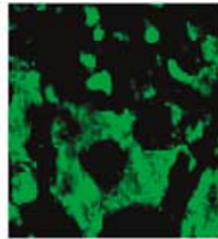

Anti-PBA3

Figure 2 (A) Immunohistochemical localisation of PEA3 $(\times 200)$ counterstained with haematoxylin and matched lgG-negative controls in human breast cancer tissue. (B) Immunohistochemical localisation of Phospho-raf $(\times 200)$ counterstained with haematoxylin and matched lgG-negative controls in human breast cancer tissue. (C) Immunofluoresence localisation of PEA3 (green) in human breast cancer tissue $(\times 630)$ counterstained with DAPI (blue). 

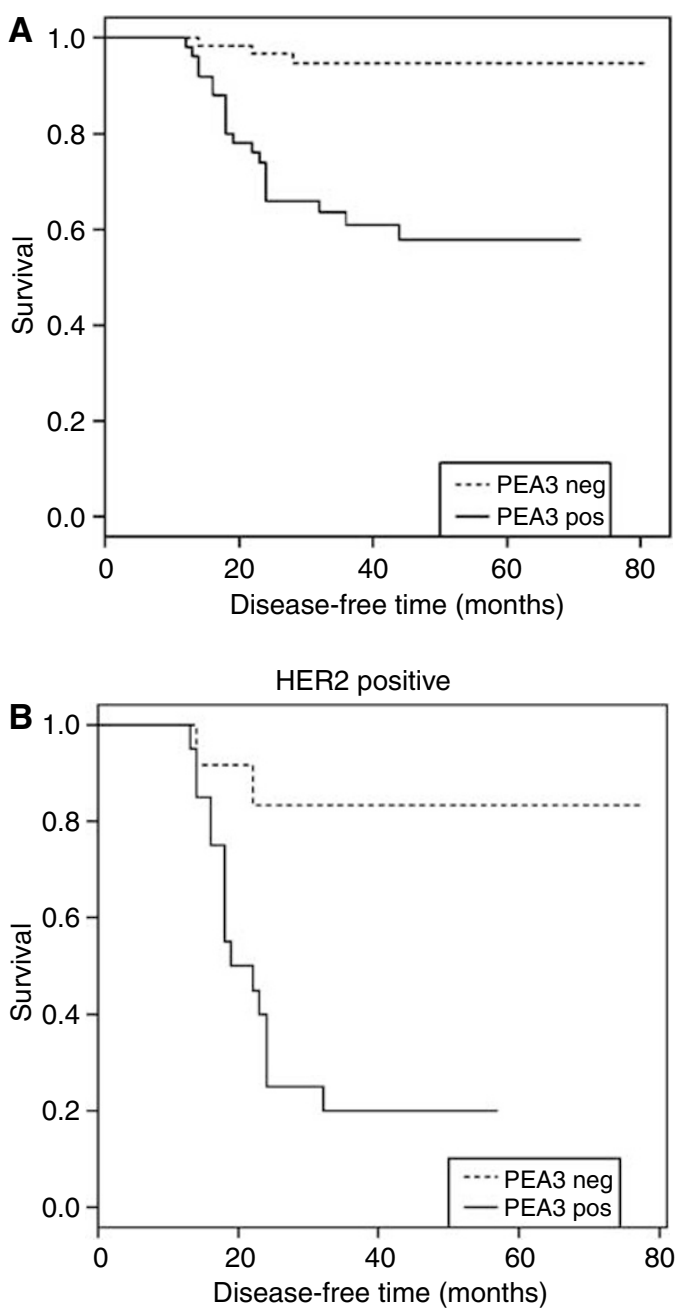

Figure 3 (A) Kaplan-Meier estimates of disease-free survival (DFS) $(n=107)$ according to PEA3 expression. (B) DFS according to PEA3 expression in HER2-positive breast tumour patients $(n=32)$.

Table 2 Relative levels of protein expression of PEA3 in primary breast tumour cell cultures in the presence of growth factors, $n=18$

\begin{tabular}{|c|c|c|}
\hline & PEA $3_{\text {stimulated }}-\mathrm{PEA} 3_{\text {control }}$ & P-value \\
\hline No. of positive patients & $14 / 18$ & \\
\hline \multicolumn{3}{|c|}{ HER2 status (median and range) } \\
\hline $\begin{array}{l}\text { Positive } \\
\text { Negative }\end{array}$ & $\begin{array}{l}534(200-860) \\
124(0-340)\end{array}$ & 0.034 \\
\hline \multicolumn{3}{|c|}{ Axillary status (median and range) } \\
\hline $\begin{array}{l}\text { Positive } \\
\text { Negative }\end{array}$ & $\begin{array}{c}338(160-660) \\
80(0-210)\end{array}$ & 0.049 \\
\hline
\end{tabular}

Relative optical density of PEA3 immunoblots both under control conditions and following stimulation with growth factors were obtained. Optical density readings were normalised to I and treated groups were expressed as a ratio. Data expressed as median and range, comparisons analysed using Wilcoxon rank sum test. These data are also represented graphically in the form of a histogram.

signal transduction pathways to alter gene expression. HER2 overexpression is associated with aggressive breast cancers and an adverse prognosis. Trastuzumab (herceptin) is a monoclonal antibody which targets HER2 and combination chemotherapy with trastuzumab is now a standard first-line treatment for women with advanced HER2 overexpressing breast cancer (Vogel et al, 2002). Recent data support trastuzumab's role in earlier stages of disease
(Romond et al, 2005). Despite these advances, a number of questions remain regarding the exact role of HER2 in breast tumour progression including the exact mechanism of HER2 transcriptional regulation. The Ets family of transcription factors play a well-documented role in breast tumour progression and have been shown to contribute to the transcriptional regulation of HER2 (Shepherd et al, 2001; Span et al, 2002). We have previously demonstrated that the growth factor EGF induces HER2 protein expression in primary breast cultures derived from patient tumours, thus implicating an activated MAPK pathway in HER2 transcriptional regulation (Myers et al, 2005). To date, assessing endogenous PEA3 protein expression in human breast cancer cell lines has proved difficult. Here, we demonstrate an upregulation in PEA3 protein expression and DNA binding within the HER2 promoter in the presence of an activated MAPK pathway and describe a relationship between regulation of PEA3 expression in response to growth factor stimulation and HER2 positivity in primary breast tumour cultures. In this study, we describe associations between co-expression of PEA3 and HER2 and time to disease recurrence.

Ets family members can be divided into 13 subgroups based on the sequence similarity of their Ets domains. PEA3 is a founding member of a subfamily of class I Ets transcription factors that also includes ER81 and ERM (Xin et al, 1992). The Ets family of transcription factors contribute to the transcriptional regulation of HER2 (Shepherd et al, 2001). The exact role of PEA3 in HER2 transcriptional regulation remains controversial with conflicting reports as to the direction of its modulation (Xing et al, 2000; Shepherd et al, 2001). Ets transcription factors are known effectors of the MAPK pathway, (O'Hagan et al, 1996), and class I family members, in particular, are targets for phosphorylation in response to stimulation. Phosphorylation of Ets sub-family members, Ets-1 and Ets-2, by MAPK-dependent pathways leads to persistent expression of tumour-related target genes including proteases such as uPA and MMPs (Yang et al, 1996; Sharrocks et al, 1997). In vitro studies provide evidence that PEA3 can be activated through phosphorylation by MAPK pathway, both through the extracellular signal-related kinase and the c-Jun $\mathrm{N}$ terminal kinase stress-activated protein kinase (Wasylyk et al, 1997). Phosphorylation via an activated MAPK pathway also represents a potential mechanism of activation of PEA3-DNAbinding (O'Hagan et al, 1996). We found that both the growth factors, bFGF and EGF, induced interaction between PEA3 and its response element, within the promoter region of HER2. In this study, growth factors, bFGF and EGF upregulated the protein expression of PEA3 in human primary tumour cell cultures. Furthermore, response to growth factor stimulation in primary breast tumour cultures associated with axillary lymph node positivity and HER2 overexpression supporting a positive role for PEA3 in breast cancer progression.

A previous study by Kinoshita et al (2002) observed PEA3 protein to be expressed exclusively in tumour tissue. We have previously correlated PEA3 protein expression with that of HER2 in a limited cohort of breast cancer patients (Fleming et al, 2004). In this study, we have examined the expression of PEA3 in relation to established clinical parameters of breast cancer. We found a positive association between PEA3 protein expression and tumour grade and axillary lymph node positivity, known poor prognostic indicators in breast cancer. In addition, PEA3 expression correlated with time to disease recurrence. Co-expression of PEA3 and HER2 significantly increased the rate of disease recurrence supporting a positive role for PEA3 in HER2-mediated oncogenesis.

Associations between co-expression of PEA3 and HER2 and reduced disease-free survival and between upregulation of PEA3 protein expression, in primary cultures, and both axillary lymph node positivity and HER 2 overexpression are suggestive of a positive role for PEA3 in HER2-mediated breast tumour progression. 


\section{REFERENCES}

Berns EM, Foekens JA, Van Staveren IL, Van Putten WL, de Koning HY, Portengen H, Klijn JG (1995) Oncogene amplification and prognosis in breast cancer: relationship with systemic treatment. Gene 159: $11-18$

Carlomagno C, Perrone F, Gallo C, De Laurentiis M, Lauria R, Morabito A, Pettinato G, Panico L, D’Antonio A, Bianco AR, De Placido S (1996) Cerb B2 overexpression decreases the benefit of adjuvant tamoxifen in early-stage breast cancer without axillary lymph node metastasis. J Clin Oncol 14: $2702-2708$

Fleming FJ, Myers E, Kelly G, Crotty TB, McDermott EW, O’Higgins NJ, Hill AD, Young LS (2004) Expression of SRC-1, AIB1 and PEA3 in HER2 mediated endocrine resistant breast cancer; a predictive role for SRC-1. J Clin Pathol 57: 1069-1074

Goel A, Janknecht R (2003) Acetylation-mediated transcriptional activation of the Ets protein ER81 by p300. P/CAF and HER2/Neu. Mol Cell Biol 23: $6243-6254$

Harvey JM, Clark GM, Osbourne CK, Allred DC (1999) Estrogen receptor status by immunohistochemistry is superior to ligand binding assay for predicting response to adjuvant endocrine therapy in breast cancer. J Clin Oncol 17: 1474-1481

Kinoshita J, Kitamura K, Tanaka S, Sugimachi K, Ishida M, Saeki H (2002) Clinical significance of PEA3 in human breast cancer. Surgery 131(Suppl 1): S222-S225

Menard S, Pupa SM, Campiglio M, Tagiabue E (2003) Biologic and therapeutic role of HER2 in cancer. Oncogene 22: 6570-6578

Myers E, Fleming FJ, Crotty TB, Kelly G, McDermott EW, O’Higgins NJ, Hill $\mathrm{AD}$, Young LS (2004) Inverse relationship between ER $\beta$ and SRC-1 predicts outcome in endocrine resistant breast cancer. $\mathrm{Br} J$ Cancer 91: $1687-1693$

Myers E, Hill AD, Kelly G, McDermott EW, O’Higgins NJ, Buggy Y, Young LS (2005) Associations and interactions between Ets-1 and Ets-2 and co-regulatory proteins SRC-1, AIB1 and NCoR in breast cancer. Clin Cancer Res 11: $2111-2122$

O’Hagan RC, Tozer RC, Symons M, McCormick F, Hassell JA (1996) The activity of the Ets transcription factor PEA3 is regulated by two distinct MAPK cascades. Oncogene 13: $1323-1333$

Romond EH, Prez EA, Bryant J, Suman VJ, Geyer Jr CE, Davidson NE, Tan Chiu E, Martino S, Paik S, Kaufman PA, Swain SM, Pisonsky TM, Fehrenbacher L, Kutteh LA, Vogel VG, Visscher DW, Yothers G, Jenkins RB, Brown AM, Dakhil SR, Mamounas EP, Lingle WL, Klein PM, Ingle JN, Walmark N (2005) Trastuzumab plus adjuvant chemotherapy for operable Her2 positive breast cancer. $N$ Engl J Med 53: $1673-1684$
Scott GK, Daniel JC, Xiong X, Maki RA, Kabat D, Benz CC (1994) Binding of an ETS-related protein within the DNase I hypersensitive site of the HER2/neu promoter in human breast cancer cells. J Biol Chem 269: $19848-19858$

Sharrocks AD, Brown AL, Ling Y, Yates PA (1997) The ETS-domain transcription factor family. Int J Biochem Cell Biol 29: 1371-1387

Shepherd TG, Kockeritz L, Szrajbe MR, Muller WJ, Hassell JA (2001) The pea3 subfamily ets genes are required for HER2/Neu-mediated mammary oncogenesis. Curr Biol 11: 1739-1748

Sorlie T, Perou CM, Tibshirani R, Aas T, Geisler S, Johnsen H, Hastie T, Eisen MB, Van de Rijn M, Jeffrey SS, Thornsen T, Quist H, Matese JC, Brown PO, Botstein D, Eystein Lonning P, Borresen-Dale AL (2001) Gene expression patterns of breast carcinomas distinguish tumour subclasses with clinical implications. Proc Natl Acad Sci USA 98: $10869-10874$

Span PN, Manders P, Heuvel JJ, Thomas CM, Bosch RR, Beex LV, Sweep CG (2002) Expression of the transcription factor Ets-1 is an independent prognostic marker for relapse-free survival in breast cancer. Oncogene 21: $8506-8509$

Vogel CL, Cobleigh MA, Tripathy D, Gutheil JC, Harris LN, Fehrenbacher L, Slamon DJ, Murphy M, Novotny WF, Burchmore M, Shak S, Stewart SJ, Press M (2002) Efficacy and safety of trastuzumab as a single agent in first line treatment of HER2 overexpressing metastatic breast cancer. J Clin Oncol 20: 719-726

Wasylyk C, Bradford AP, Gutierrez-Hartman A, Wasylyk B (1997) Conserved mechanisms of Ras regulation of evolutionary related transcription factors Ets-1 and Pointed P2. Oncogene 14: 899-913

Xia WY, Lien HC, Wang X, Pan Y, Sohin A, Kuo YH, Chang KJ, Zhou X, Wang H, Yu Z, Hotobagyi G, Shi DR, Hung MC (2006) Expression of PEA3 and lack of correlation between PEA3 and HER-2/neu expression in breast cancer. Breast Cancer Res Treat 98: 295-301

Xin JH, Cowie A, Lachance P, Hassell JA (1992) Molecular cloning and characterization of PEA3, a new member of the Ets oncogene family that is differentially expressed in mouse embryonic cells. Genes Dev 6: $481-496$

Xing X, Wang SC, Xia W (2000) The ets protein PEA3 suppresses HER-2/neu over expression and inhibits tumorigenesis. Nat Med 6: $189-195$

Yang BS, Hauser CA, Henkel G (1996) Ras mediated phosphorylation of a conserved threonine residue enhances the transactivation activities of cEts-1 and c-Ets-2. Mol Cell Biol 16: 538-547 